\title{
Stage II Renal Cell Cancer AJCC v8
}

National Cancer Institute

\section{Source}

National Cancer Institute. Stage II Renal Cell Cancer AJCC v8. NCI Thesaurus. Code C140324.

Stage II includes: T2, N0, M0. T2: Tumor measuring more than $7 \mathrm{~cm}$ in greatest dimension, limited to the kidney. N0: No regional lymph node metastasis. MO: No distant metastasis. (AJCC 8th ed.) 